\title{
Upper Miocene deposits from El Ma Labiod (Tébessa, Northeastern Algeria): Sedimentology, micropaleontology and paleoenvironmental implications
}

\author{
Abdelhakim Benkhedda ${ }^{1}$, Nabil Defaflia ${ }^{1}$, Amine Cherif $^{2}$, Mostapha Benzina ${ }^{3}$, Rabah Kechiched ${ }^{4}$, \\ Mohammed Nadir Naimi ${ }^{2}$, and Muriel Djerrab-Ruault ${ }^{5}$
}

Received 28 June 2020; accepted 1 March 2021; published 1 March 2022.

The Miocene sediments have been the subject of several studies over the Mediterranean region especially from a bio-lithostratigraphic and geodynamic studies point of views. The Miocene deposits of the El-Ma Labiod located in Tébessa region (Northeastern Algeria) were investigated through the present research. This region is an area that was not extensively studied, and the available findings remain debatable. This study is conducted to clarify paleoenvironment conditions on the basis of a sedimentological approach including grain size, morphoscopy examination, and mineralogical analysis by XRD on the one hand, and by investigating the fauna contents on the other hand. The results reveal that Miocene sediments can display multiple modes of transport according to grain size. The XRD analyses on the clayey fraction have evidenced the presence of three clay minerals groups, mainly consisting of Kaolin-serpentine (kaolinite), minor smectite (Di-smectite), and sepiolite-plagorsikite (sepiolite) reflecting wholly warmer climate while the dominance of kaolinite indicates rather wet paleoclimate exposure. This study reports for the first time, a record of foraminifera and ostracods contents in the upper Miocene from the studied area. Based on these sedimentological and micropaleontological data, the Miocene deposits are more likely linked to a marginallittoral depositional environment. KEYWORDS: Sedimentology; microfauna; marginal-littoral; Miocene; Tebessa; Northeastern Algeria.

Citation: Benkhedda, Abdelhakim, Nabil Defaflia, Amine Cherif, Mostapha Benzina, Rabah Kechiched, Mohammed Nadir Naimi, and Muriel Djerrab-Ruault (2021), Upper Miocene deposits from El Ma Labiod (Tébessa, Northeastern Algeria): Sedimentology, micropaleontology and paleoenvironmental implications, Russ. J. Earth. Sci., 22, ES1003, doi:10.2205/2021ES000768.

\footnotetext{
${ }^{1}$ Laboratory of Sedimentary Environment, Mineral and Hydric Resources of Algeria Eastern, Department of Earth and Universe Sciences, Larbi Tebessi University, Tébessa, Algeria

${ }^{2}$ Department of Sciences of the Earth and the Universe, University of Ouargla, Ouargla, Algeria

${ }^{3}$ Laboratoy of Research no 25 "PRHPM-LECT", University of Tlemcen, Tlemcen, Algeria

${ }^{4}$ Laboratoire des Reservoirs Souterrains: Petroliers, Gaziers et Aquiferes, Universite de Ouargla, Ouargla, Algeria

${ }^{5}$ Faculty of Nature and Life Sciences and Sciences of the Earth and the Universe, University of 08 May 1945, Guelma, Algeria
}

\section{Introduction}

Recently, several works were conducted on the Miocene marine series from the Northern Algeria [Benzina et al., 2019, Cherif et al., 2021, Naimi et al., 2020, 2021]. The Miocene sediments are cropping out in Tébessa region and belonging to the southern border of the Mediterranean Sea (Northeastern Algeria). The Miocene series are 50 to

Copyright 2021 by the Geophysical Center RAS. http://rjes.wdcb.ru/doi/2021ES000768-res.html 
$200 \mathrm{~m}$ thick. The lower and the middle Miocene are made of sandstones, sands, marls and conglomerates overlying a transgressive surface (Cretaceous and even Triassic), whereas the upper Miocene is represented by red marls, sands and sandstones.

The first work on the Miocene of the Tébessa region was carried out by Brives [1919, 1920 who reveals the presence of Dinotherium teeth in the sands quarry of El Kouif. The lower and middle Miocene had been mapped by Durozoy 1956 as sandstone and siliceous puddings, whereas the Vindobonian (upper Miocene) as clays and marls. Morel 1957 have reported the existence of external bivalve moulds (Ostrea crassissima). In addition, Dubourdieu et al., 1959 have mentioned the presence of Neoaveolinea foraminiferous in the Miocene of Mesloula. Vila 1977 have cited and described an important list of foraminifera in the lower and middle Miocene in Koudiat Mami and Rahia regionand represented by Uvigerinasp., Cibicidessp., Haplophragmoides sp., Ammonia beccarii (LINNE), Spiraplectaminacarinatad'ORB, Textularia subangulata d'ORB, Nonion boueanumd'ORB, Eponides bertheletianus (REUSS) and Globigerinoidestrilobus (REUSS). Previously, the cropping deposit in the El Ma Labiod region, representing the studied area for this investigation, had been considered by Hamimed and Kowalski 2001 as an azoic series and often attributed to the upper Miocene according to lithological correlation with similar dated Miocene sediments of Mechta Remila and Koudiat Naga in the north of Tébessa [Kowalski et al., 1995a, 1995b.

The studied area is located in the locality of $\mathrm{El}$ Hadjra Safra village (Tébessa, Algerian-Tunisian borders), at $600 \mathrm{~km}$ of Capital Algiers (Figure 1). The El Ma Labiod plain constitutes the eastern part of the Saharan Atlas, bordered to the north by Djebel Doukkane, Djebel Bourouman and Djebel Anauan. To the South, by Djebel Boudjelal, Dalaa and El Gallal, and the Oued Chéria and Oued Outat El Adjadj to the western part. The Koudiat Sidi Salah area nearby Tunisian boundary represents the eastern limit.

The present paper aims at providing a sedimentological analysis and to detail microfauna content of the Upper Miocene strata exposed at El Ma Labiod (Tébessa, northeastern Algeria). In addition, this study constitutes a contribution to the poorly understood framework of Miocene deposits in the studied region using grain size and morphoscopy approaches, as well as preliminary foraminifera taxon listing that contributes to the identification and the characterization of depositional environment.

\section{Geological and Paleoenvironmental Background}

The northwest African Alpine chain, located to the north of the Saharan platform is represented by two distinct segments: (i) the Maghrebides (RifTell orogen) to the northern part, extending from Morocco to Algeria [Durand-Delga, 1969, Halamski and Cherif, 2017), and (ii) the Atlasic domain to the south, represented in Algeria by the Saharan Atlas (sensu stricto), Zibane and Aures [Kazi-Tani, 1986 .

The studied area belongs to the Tébessa Mounts in the northeastern part of the Algerian Atlasic domain (Figure 1a and Figure 1b). In this region, sedimentary successions outcrop and they are comprised from Triassic to Quaternary continental and marine sediments. The Cretaceous and Cenozoic deposits are often affected by Eocene Atlasic tectonic events and are pierced in many locations by Triassic diapirs [Blès and Fleury, 1970, Dubourdieu, 1956, Durozoy and Bouillon, 1956, Vila, 1980. The marine Mesozoic sediments of Tébessa region are $7000 \mathrm{~m}$ average thickness [Dubourdieu, 1956 and characterized by absence of Jurassic and lowermost cretaceous that could be explained by ante-Aptian diapiric movements [Othmanine, 1987. The Triassic diapirs are made of a Germanic facies type, represented mainly by gypsumrich marls, clays, anhydrite, dolomite, with abundant bivalves. The overlying Cretaceous rocks are represented by the Barremian-Aptian dolomites and oolitic limestones. The mid-Cretaceous (Albian to Turonian) is represented by marls and limestones include rich ammonites, bivalves (oysters and rudists), echinoids, belemnites and gastropods [Mendir et al., 2019, reflecting a deep external platform to upper slope environment under poor-oxygen conditions [Ruault-Djerrab and Kechid-Benkherouf, 2011. The planktonic microfauna and geochemical analysis allowed the evidence of the OAE-2 in this region [Ruault-Djerrab et al., 2012, 2014, Salmi-Laouar et al., 2018. In the upper Cretaceous succession, a marly sedimen- 


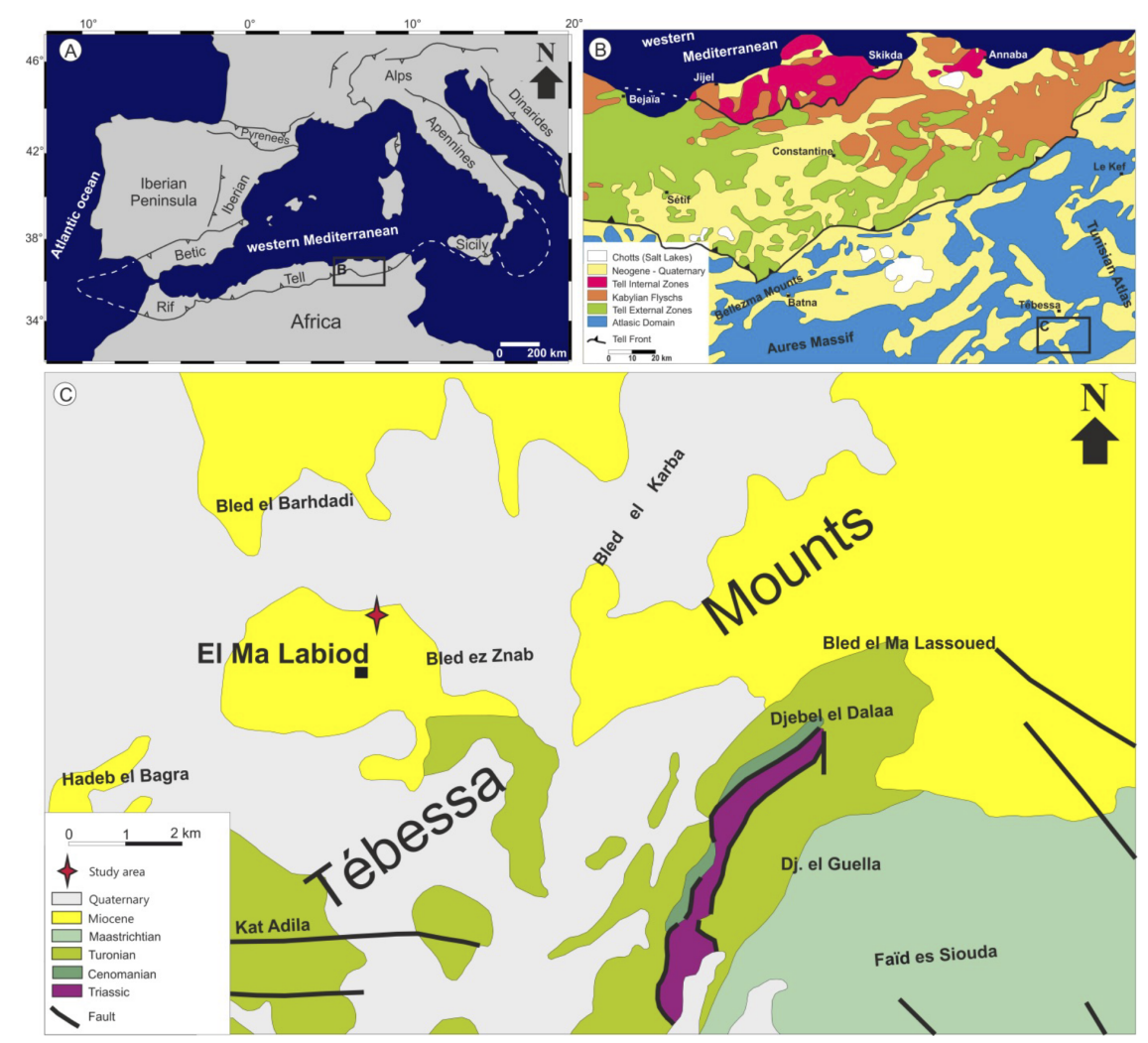

Figure 1. (A) Geographical location of the studied area (Modified after Soria et al., 2005); (B) Structural map of Eastern Algeria (modified after Benhenni et al., 2019); (C) Simplified geological map of the El Ma Labiod region, Tébessa (extracted from Geological Map of Algeria, after Algerian Geological Survey Agency "ASGA").

tation is settled, and this succession is observed to have temporarily been interrupted by fish-bearing chalky limestone essentially at the middle Campanian.

The Paleocene and Eocene series are characterized by marls, limestones rich in shells, shark teeth and nummulites, as well cherty nodules and host many phosphorite layers. The phosphatic material includes pellets, coprolites, enameloid and dentine of marine fish teeth and is cemented by argillaceous or carbonaceous matrix [Kechiched et al., 2016, 2018. These Paleocene/Eocene phosphorites display glauconite enrichment which may be resulted in reworking processes of pre-existing phosphatic particles before their deposition and final burial in a sub-toxic to sub-reduced environment [Chabou-Mostefai, 1987] Kechiched et al., 2018. In addition, Kechiched et al. 2020 have evoked a geochemical signature reflecting a probable onset of the Paleocene-Eocene Thermal Maximum (PETM), which is considered as one of the most important global warming events in Cenozoic [Jenkyns, 2010].
The Miocene series are characterized by marine and continental deposits unconformably overlying the Cretaceous strata [Hamimed and Kowalski, 2001.

It is represented by Miocene sandstones, clays, marls, carbonates and conglomerates. These strata are overlain by compact reddish clays, well-cemented conglomerates and sands attributed to the Pliocene [Durozoy, 1956]. The Miocene strata are subdivided into three informal stratigraphic units: Burdighalian, Langhian-Serravallian, and Tortonian [Hamimed and Kowalski, 2001. Kowalski et al., 1995a, 1995b.

The Burdigalian Units are only found in the Northern basin represented by marls and sandstone rocks, interpreted as neritic environment often coastal fascias [Hamimed, 2004, Kowalski et al., 1995a.

The Langhian-Serravallian unit in Northern ba$\sin$ is characterized by marine sedimentation manifested by ferruginous crust and significant erosion and reflecting a littoral environment [Hamimed, 
2004. However, the Southern basin unit is characterized by deltaic facies, including convolute structures and slumping features, cross to oblique bedding [Hamimed and Kowalski, 2001, Kowalski et al., 1995b. The Tortonian unit in the Northern basin consists of a coastal environment showing debris of benthic fossils and wavy ripple [Kowalski et al., 1995a.

The study area represented by El Ma Labiod, corresponds to Miocene sand cropping out in the "Mio-Plio-Quaternary graben". The Cretaceous is represented by fossiliferous limestones. Moreover, thin lower to middle Eocene phosphate-rich deposits crop out [Vila, 1980]. The Miocene sediments are deposited into fluvial, deltaic, lacustrine environments [Hamimed et al., 2001]. Despite the absence of any biostratigraphic indicators, a Tortonian age was attributed to these deposits [Hamimed, 2004, Hamimed and Kowalski, 2001.

\section{Materials and Methods}

Representative samples throughout the studied region were collected where two types of laboratory analyses were carried out.

\subsection{Sedimentological Analysis}

This approach includes grain size analysis, carbonate contents, morphoscopy, and diffractometry. The thirty-five (35) samples had been sieved at a mesh of $2 \mathrm{~mm}$ size, and dried at a temperature less than $40^{\circ} \mathrm{C}$. The grain size analysis was performed using He-Ne Red Laser at $632 \mathrm{~nm}$ for the detection of large particles, and blue diode at $466 \mathrm{~nm}$ for the fine's particles. The calculations of parameters and sands indices were performed according the method of (Mastersizer, 2000, https://www.malvernpanalytical.com/en/support/ product-support/mastersizer-range).

The morphoscopic study after Cailleux and Tricart 1963 is applied on the ambient decarbonated quartz grains (0.5 and $0.25 \mathrm{~mm}$ ) under binocular magnifying glass, examining the appearance and grain-shape allocation which allows characterizing the mode of transport. Calcimetry work which consists of determining the percentages of calcium carbonate on $0.5 \mathrm{~g}$ of crushed and dried sediments $(<2 \mathrm{~mm})$ was performed using Bernard calcimeter.
To enhance our knowledge on mineralogical characteristics, the X-diffraction analyses following the focused method by Holtzapffel 1985 were carried out on oriented aggregates using a diffractometer with a copper anticathode. The device settings are optimized to work at low angles $\left(2 \theta<30^{\circ}\right)$ where diffract in most cases of silty and clay minerals.

\subsection{Micropaleontological Analysis}

Twenty (20) samples of sands and clay material were treated using classic series of sieves $(250 \mu \mathrm{m}$ to $100 \mu \mathrm{m})$ and carefully examined by binocular microscopy. The following indices were calculated:

a) The paleobathymetry index: The paleobathymetry index was calculated as $[P /(P+B)] ; P$ refers to the number of planktonic foraminifera, whereas $P+B$ is the total number of planktonic and benthic foraminifera. This index has been used by Kouwenhoven 2000 to estimate the paleobathymetric evolution. In addition, Hebib and Belkebir 2006 have successfully used it to estimate the openness of the environment on the offshore setting.

b) The dominance index [Goodman, 1979]: The dominance index $(D)$ is calculated as $(N 1+N 2) / N T$ in which $N 1$ refers to the number of individuals of the most abundant species, $N 2$ as the number of individuals of the second most abundant species, whereas $N T$ represents the total number of specimens sin the same sample. This index can be defned as the percentage of the most abundant species [Levin and Cage, 1998].

c) The diversity index [Shannon and Weaver, 1949: This index is calculated using the following formula:

$$
I s c=-\sum\left[\left(q_{i} / Q\right) \times \operatorname{Ln}\left(q_{i} / Q\right)\right]
$$

where $Q$ represents the total number of individuals in each level and $q_{i}$ refers to the number of individuals counted for each species. Diversity indices provide more information about community composition than simple species richness which is used to understand community structure as well. 


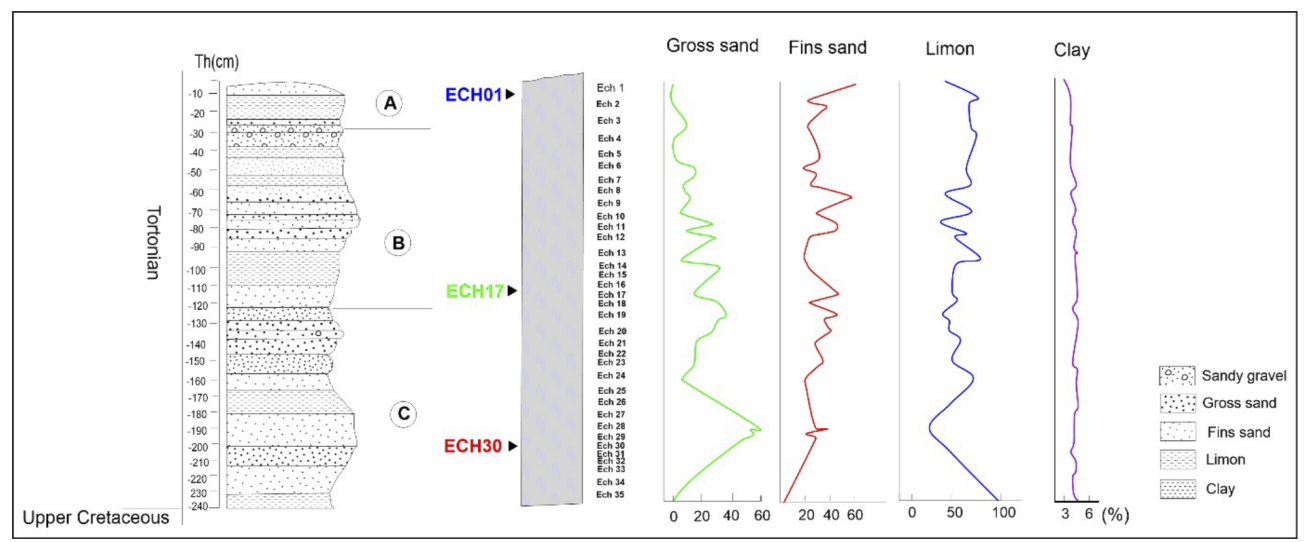

Figure 2. Lithological log and distribution of particles sizes in the El Hadjrasafra region.

\section{Results}

\subsection{Sedimentological Analysis}

The grains size analysis allows distinguishing a succession into three (3) grain-size class as shown in Figure 2, In detail, they are described as following:

- A. It consists mainly in fine grains of sands, rarely coarse, containing thin sandy-silt layers, rare gravel grains and small size pebbles.

- B. This class is formed mostly by silty-argillaceous matrix overlain by silty sands with rarely fine, fine-medium to coarse sands layers.

- C. It is dominated by silty matrix and silty sands subordinating fine to coarse sands layers.

\subsection{Micropaleontological Analysis (Foraminifera and Ostracoda)}

Broadly, the studied sands from El Hadjra Safra area reveal rich foraminifera associations, representing the widespread of benthic foraminifera as well as Brizalina sp. group and planktonic foraminifera Neogloboquadrina acostaensis (index species of N.acostaensis biozone). According to the Standard Mediterranean Sea scale, the top of El Hadjra Safra section consists of rich ostracodes level $(\mathrm{Ta}-$ ble 1), represented by Semicytherura? ssp., Paracypris? ssp., Phlyctenophora? ssp., Cytherella? ssp., Kangarina? ssp., Grinioneis? ssp., Tendocythere? ssp. Note that similar forms have been documented in marginal Miocene deposits from the
Mediterranean regions. Notably in North Africa: Libya [Gammudi, 1993], Egypt [Shahin, 2000], and in southern Europe: Spain, France and Portugal [Abad et al., 2005].

The foraminifera are abundant and diversified in the upper part from $-5 \mathrm{~cm}$ to $-160 \mathrm{~cm}$. For the palecological parameters, the Shannon diversity index is more than 2 (Figure 3). According to Murray 1991a, 1991b, in open marine outer shelf to slope environments, the values of Shannon diversity can reach the value of 3 and otherwise, this index indicates instability conditions. The curve of the abun-

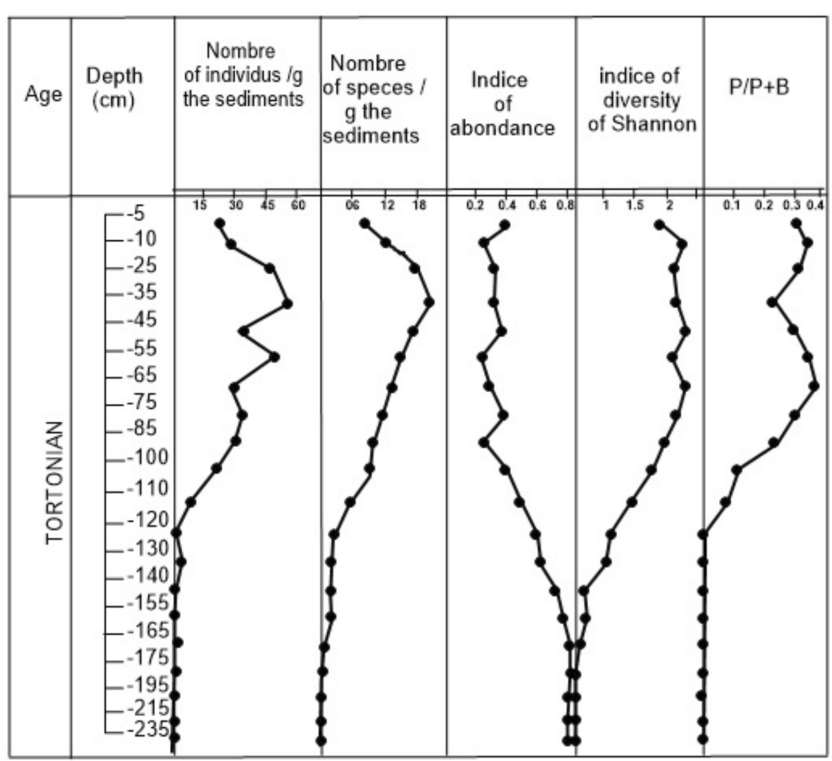

Figure 3. Results of ecological parameters in El Hajra Safra (El Ma Labiod). 
Table 1. Distribution of Microfauna Along the El Hadjra Safra Section

\begin{tabular}{|c|c|c|c|c|c|c|c|c|c|c|c|c|c|c|c|c|c|c|c|c|c|c|c|c|}
\hline 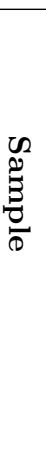 & 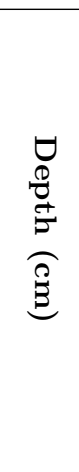 & $\underset{\substack{0 \\
\stackrel{9}{9}}}{0}$ & 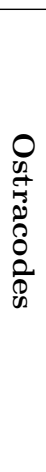 & 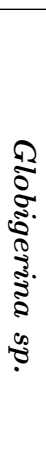 & 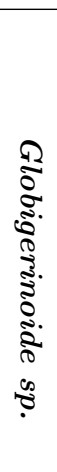 & 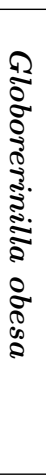 & 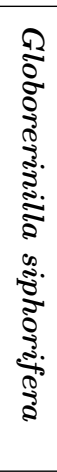 & 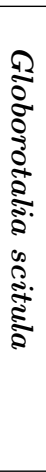 & 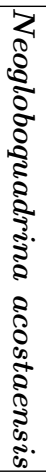 & 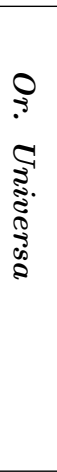 & 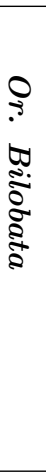 & 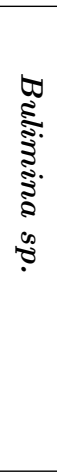 & 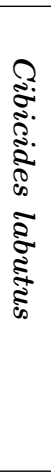 & 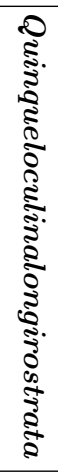 & $\begin{array}{l}z \\
\vdots \\
\delta \\
0 \\
\infty \\
\vdots \\
\vdots \\
\vdots \\
0 \\
0 \\
0\end{array}$ & 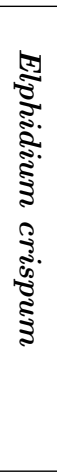 & 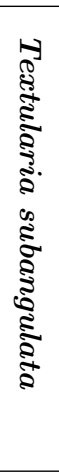 & 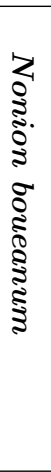 & 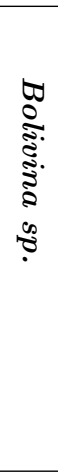 & 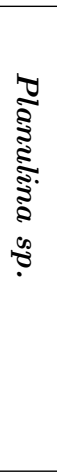 & 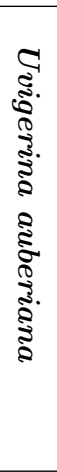 & 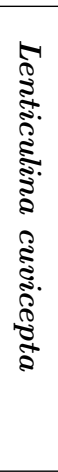 & 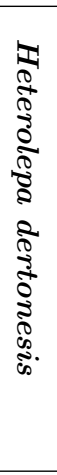 & $\begin{array}{l}\text { Remarks on the } \\
\text { assemblage }\end{array}$ \\
\hline 1 & -5 & - & - & + & - & - & - & + & - & - & - & - & - & + & - & + & + & - & + & + & - & - & $x$ & Moderately rich \\
\hline 2 & -15 & - & - & + & + & + & + & + & + & - & - & - & + & - & - & + & + & - & - & - & + & + & $x$ & Moderately rich \\
\hline 3 & -25 & + & + & + & + & + & + & + & + & - & - & - & + & - & + & + & + & - & + & + & + & + & + & $\begin{array}{l}\text { Very rich, well } \\
\text { preserved }\end{array}$ \\
\hline 4 & -35 & + & $x$ & + & + & + & + & - & + & + & + & + & + & + & $x$ & + & + & - & + & + & + & + & + & $\begin{array}{l}\text { Very rich, well } \\
\text { preserved }\end{array}$ \\
\hline 5 & -45 & - & $x$ & + & + & + & + & + & + & - & - & + & + & - & $x$ & + & + & + & + & + & $\times$ & $x$ & $x$ & $\begin{array}{l}\text { Very rich, well } \\
\text { preserved }\end{array}$ \\
\hline 6 & -55 & + & - & + & $x$ & + & + & + & + & - & - & + & + & - & $\times$ & + & + & + & + & + & - & $\times$ & $\times$ & $\begin{array}{c}\text { Moderately rich, } \\
\text { badly preserved }\end{array}$ \\
\hline 7 & -65 & + & - & $x$ & $\times$ & + & $x$ & + & + & - & - & $\times$ & + & - & $x$ & + & + & + & - & + & - & $\times$ & $\times$ & $\begin{array}{l}\text { Moderately rich, } \\
\text { badly preserved }\end{array}$ \\
\hline 8 & -75 & + & - & $x$ & $x$ & $x$ & $\times$ & + & $x$ & - & - & $\times$ & + & - & - & + & + & $\times$ & - & + & - & - & $x$ & $\begin{array}{c}\text { Moderately rich, } \\
\text { badly preserved }\end{array}$ \\
\hline 9 & -85 & + & - & - & - & $\times$ & $x$ & $x$ & $x$ & - & - & $\times$ & $x$ & - & - & + & + & $\times$ & - & $\times$ & - & - & - & $\begin{array}{c}\text { Moderately rich, } \\
\text { very badly preserved }\end{array}$ \\
\hline 10 & -100 & - & - & - & - & $x$ & - & $x$ & $x$ & - & - & $x$ & $x$ & - & - & + & + & $\times$ & - & $x$ & - & - & - & $\begin{array}{c}\text { Moderately rich, } \\
\text { very badly preserved }\end{array}$ \\
\hline 11 & -110 & - & - & $x$ & - & - & - & $x$ & - & - & - & $\times$ & - & - & - & $x$ & + & $\times$ & - & - & - & - & - & $\begin{array}{c}\text { Rare, badly } \\
\text { preserved }\end{array}$ \\
\hline 12 & -120 & - & - & - & - & - & - & - & - & - & - & $x$ & - & - & - & $x$ & + & - & - & - & - & - & - & $\begin{array}{c}\text { Rare, badly } \\
\text { preserved }\end{array}$ \\
\hline 13 & -130 & - & - & - & - & - & - & - & - & - & - & $\times$ & - & - & - & $x$ & + & - & - & - & - & - & - & $\begin{array}{c}\text { Rare, badly } \\
\text { preserved }\end{array}$ \\
\hline 14 & -140 & $x$ & - & - & - & - & - & - & - & - & - & - & - & - & - & $x$ & $\times$ & - & - & - & - & - & - & $\begin{array}{c}\text { Rare, badly } \\
\text { preserved }\end{array}$ \\
\hline 15 & -155 & $x$ & - & - & - & - & - & - & - & - & - & - & - & - & - & $x$ & $x$ & - & - & - & - & - & - & $\begin{array}{c}\text { Rare, badly } \\
\text { preserved }\end{array}$ \\
\hline 16 & -165 & $\times$ & - & - & - & - & - & - & - & - & - & - & - & - & - & $x$ & $\times$ & - & - & - & - & - & - & $\begin{array}{c}\text { Rare, badly } \\
\text { preserved }\end{array}$ \\
\hline 17 & -175 & $x$ & - & - & - & - & - & - & - & - & - & - & - & - & - & $x$ & $x$ & - & - & - & - & - & - & $\begin{array}{c}\text { Rare, badly } \\
\text { preserved }\end{array}$ \\
\hline 18 & -190 & $x$ & - & - & - & - & - & - & - & - & - & - & - & - & - & - & - & - & - & - & - & - & - & Very rare \\
\hline 19 & -215 & $x$ & - & - & - & - & - & - & - & - & - & - & - & - & - & - & - & - & - & - & - & - & - & Very rare \\
\hline 20 & -235 & $x$ & - & - & - & - & - & - & - & - & - & - & - & - & - & - & - & - & - & - & - & - & - & Very rare \\
\hline
\end{tabular}

dance index, is low often inversely proportional to ing that benthic foraminifera are more abundant that of the Shannon diversity index, hardly exceeds than planktonic foraminifera. From $-160 \mathrm{~cm}$ to the value of $50 \%$. In addition, $P / B$ ratio varies $-235 \mathrm{~cm}$, the samples revealed only rare individubetween 1 and $35 \%$ in the upper part, indicat- als that are badly preserved. 


\section{Discussion}

The terrigenous fraction of the study section consists generally of very fine to large-size grains Figure 2 and Figure 7). The fine fraction is represented by of limons (silt) of $55 \%$ and fine sands $30 \%$ whereas the remaining fractions correspond to low proportions of coarse sands. The grain size results are summarized in Figure 4 Figure 7 where interpretations can be synthesized as the following:

- a. The upper part shows parabolic curves (Figure 4 corresponding to immature sands, which are affected by reworking. The curves mode of this type corresponds to silty dominant sediments and fine sands [Riviére, 1977], whereas the clay fraction occurs in a small percentage. This type of granofacies corresponds to sediments deposited by excess of charge.

- b. The middle and lower part from the studied section display hyperbolic curves Figure 4) reflecting calm environment however, a sedimentation by settling can be also suggested and a progressive reduction of the energy of the transport agent [Pinot, 1994], while sedimentation was occurred free accumulation [Tricart, 1965].

Furthermore, the logarithmic to sub-logarithmic cumulative curves in samples 1, 17 and 30 Figure 4) are typical for silty sediments, indicating a calm environment in which deposition is related to load excess and to the decrease of energy velocity in addition to the variation of the dynamics and the different contributions in the El Ma Labiod

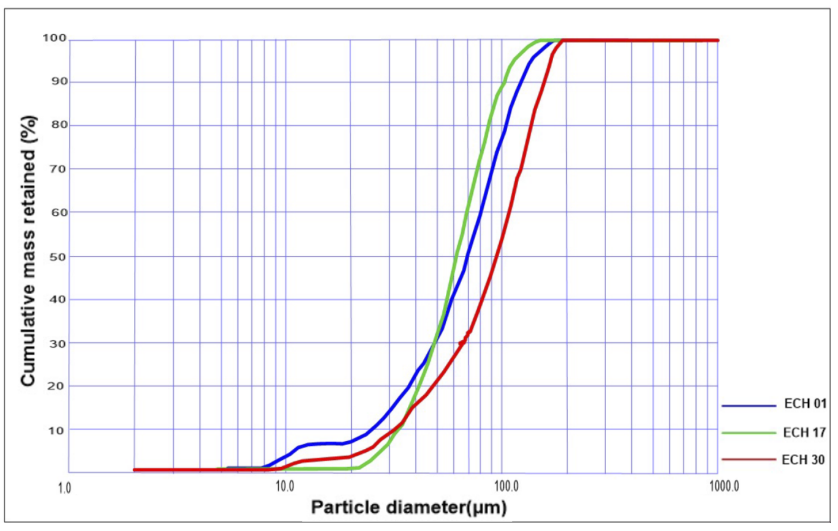

Figure 4. Cumulative curves: (Blue): ech.01, (Green): ech.17, (Red): ech.30. region [Anderson, 2007, Defaflia, 2014, Fournier, 2012, Folk and Ward, 1957, Inman, 1952, Laouini et al., 2019, Miskovsky, 2002, Pye and Blott, 2004: Riviére, 1977, Verger, 1963.

The calculated coefficients of grain size characteristics are summarized in Figure 5. They show

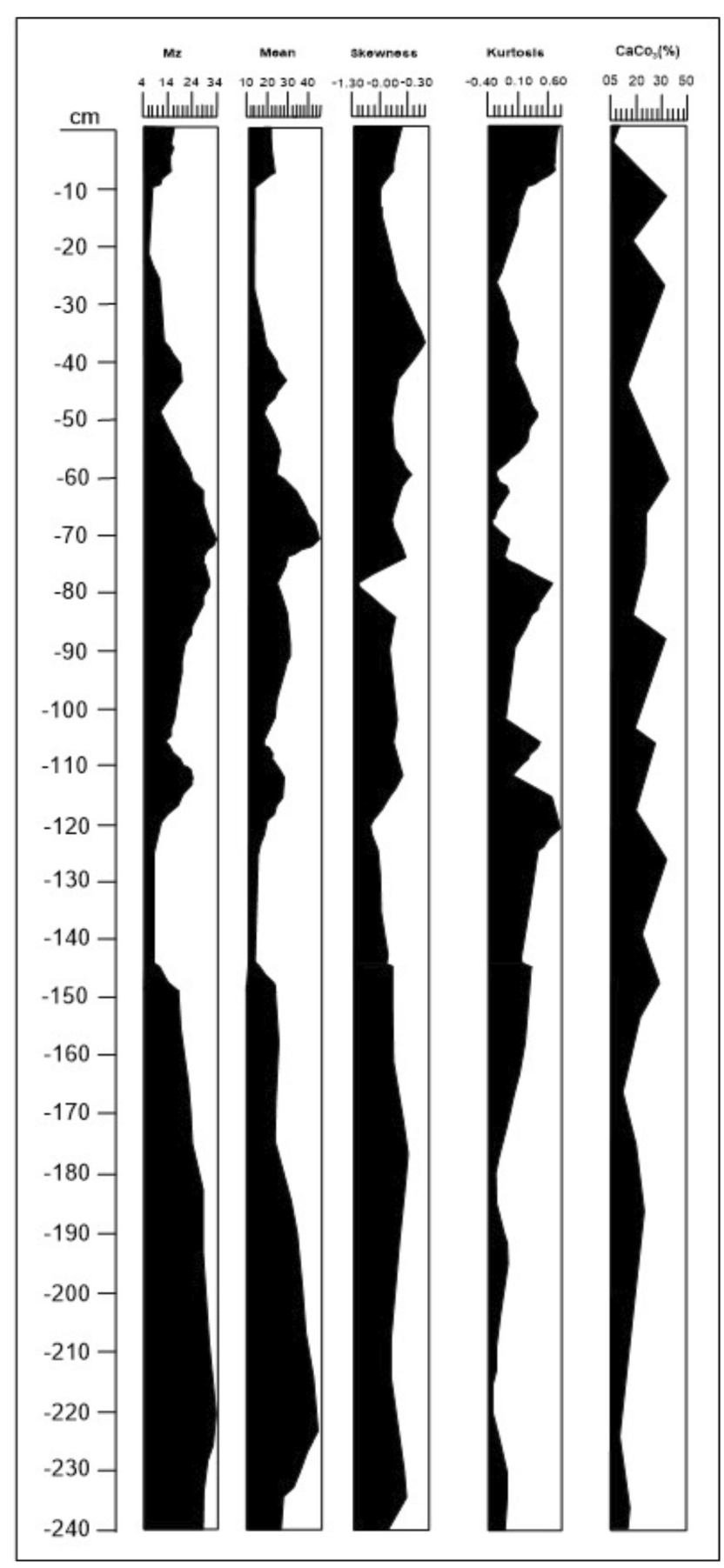

Figure 5. The different size of the calculated indices. 


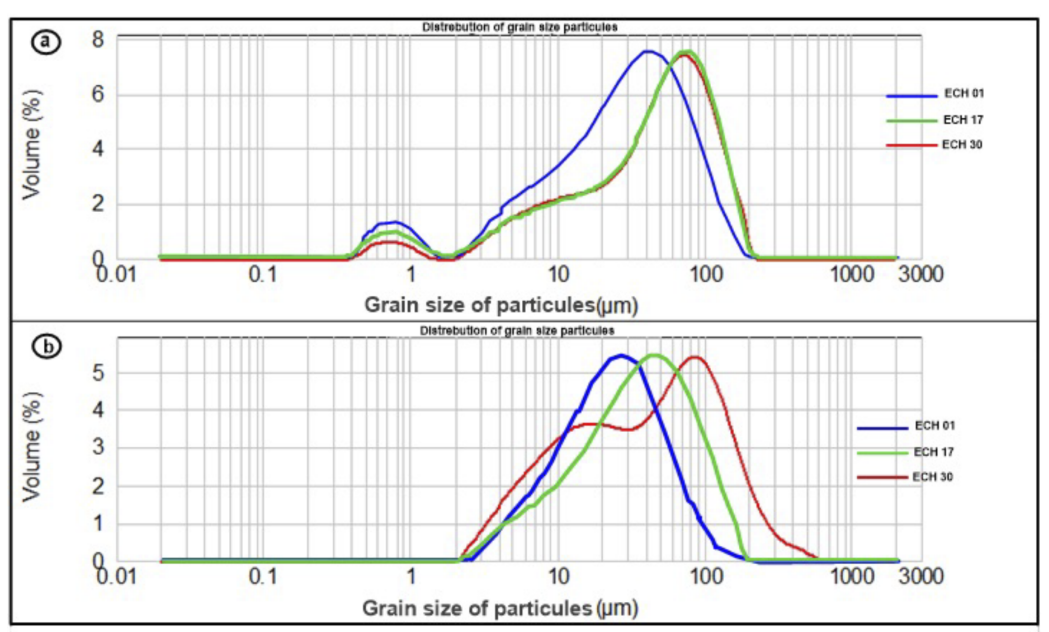

Figure 6. (a) Sample's frequencies curves: (Blue): ech.01, (Green): ech.17, (Red): ech.30; (b) Samples frequencies curves: (Blue): ech.01, (Green): ech.17, (Red): ech.30 (decarbonized).

lower to medium mean values (0.40 to 3.40$)$, due to the predominance of the silto-sandy fractions. For Kurtosis values, they range from -0.40 to 0.60 reflecting coarse to very coarse silts. The Skewness values are negative or close to zero ( -1.30 to 0.30$)$, with fine grains spreading (very fine asymmetric). For carbonate contents, the $\mathrm{CaCO}_{3}$ values display $5 \%$ to $40 \%$ contents that may be linked to precipitation of previously dissolution of the surrounding limestone reliefs as for instance Maastrichtian limestones.

The frequency curves are mainly unimodal and bimodal type (Figure $6 \mathrm{a})$. They indicate monogenic to polygenic sands. Leptokurtic type defines very poorly sorted sediments, consisting of fine sands, clays and silts whereas; platykurtic and magnetically type reflect well sorted sediments consisting of fine sands. After decarbonization, the curves of the majority of samples do not change significantly but the fractions of less than $1 \mu \mathrm{m}$ are disappeared (Figure 6 0 ).

The diagram of the particle size denomination of fine sediment shows that the sediments are mainly composed of silt and sand, with dominant silt in the upper parts (Figure 7).

The morphoscopy of quartz grains (Figure 8) suggests the co-existence of blunt or sub-blunted glow (BG) with a percentage of $72 \%$, referred to a fluvial transport from the surrounding area as Cretaceous limestone reliefs where limestone grains were founded. The round-mats (RM) grains are averaging low frequency compared to BG representing only $18 \%$ of the sediments from the uppermost of the section, including ferruginous coating, linked to pedogenesis processes. The not-worn grains (NW) are 10\%, these particles were transported by the winds (aeolian transport) from the neighbouring desert areas or are linked to weathering sediments.

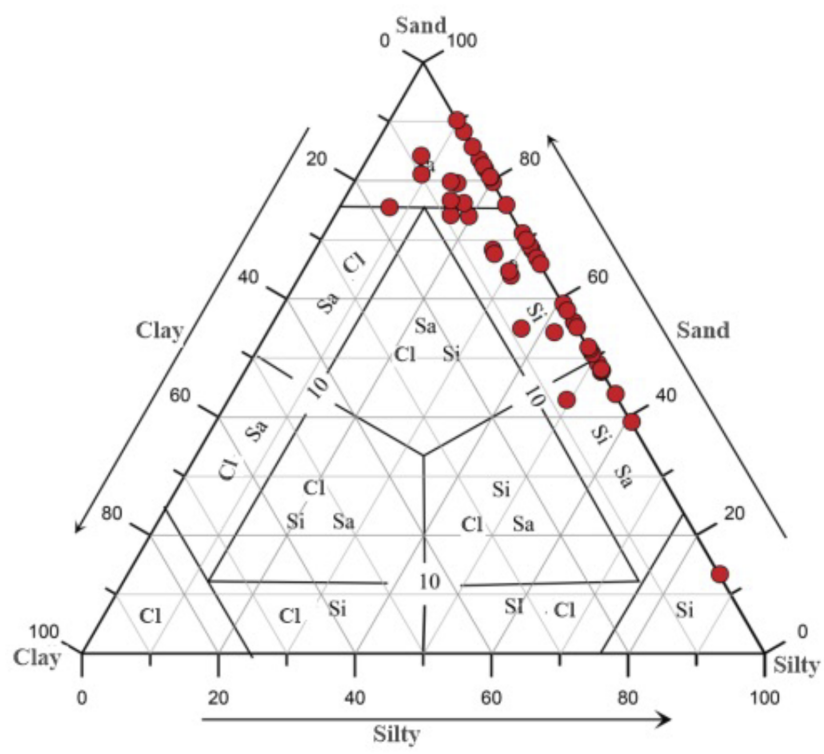

Figure 7. Ternary diagram of the particle size denomination of fine sediment. 


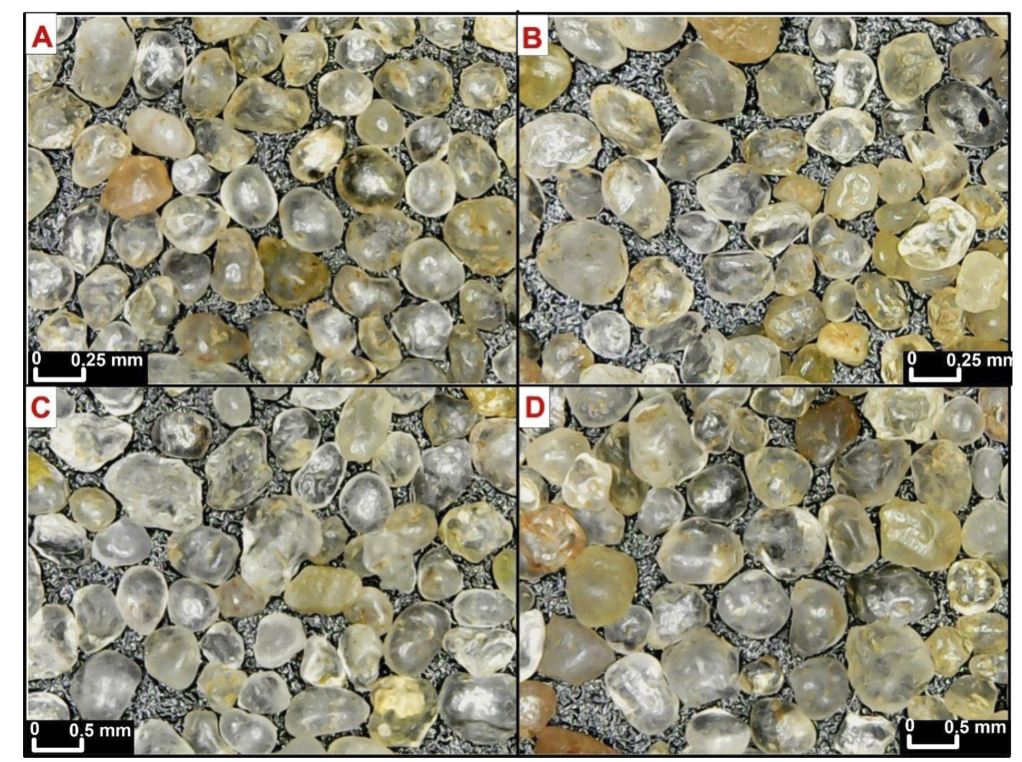

Figure 8. Quartz grains morphoscopy showing the abundance of blunted glow grains, (A) Ech.01; (B) Ech.10; (C) Ech.17; (D) Ech.35.

The mineralogical analysis of clayey fraction (Figure 9) allow distinguishing three (3) mineral groups: (1) smectite (Di-smectite and the most abundant indicating poor crystallinity) [Chameley, 1971. Millot, 1964 Paquet, 1969 and fractions associated under warm climate condition [Chameley, 1971, (2) kaolin-serpentine which is the most abundant in a hot and humid climate condition, and (3) sepiolite-plagorsikite group (sepiolite) which is formed in cold and/or dry climate condition; such mineral groups which had been also recorded from the Mediterranean regions are mainly brought by rivers [Chameley, 1971].

Kowalski et al. 1995b have mentioned that the studied area consists of azoic strata, and through lithological calibration with sediment of the surrounding area, they attributed the same age of Miocene as Mechta Remila and Koudiat Naga sediment to the north of Tébessa. However, this study looks for the biostratigraphic revision on the basis of planktonic foraminifera. For instance, in the upper part of the succession, we identified the first common occurrence (FCO) of N.acostaensisdated at $10.57 \mathrm{Ma}$. Sprovieri et al. 2002 and Lourens et al. 2005 have attributed the bioevent to the Late Miocene (Tortonian) at $10.55 \mathrm{Ma}$ and it refers to the base of N.acostaensis biozone corresponding to Zone N16 [Blow, 1969] and MMi 11, Lirer et al. 2019 .
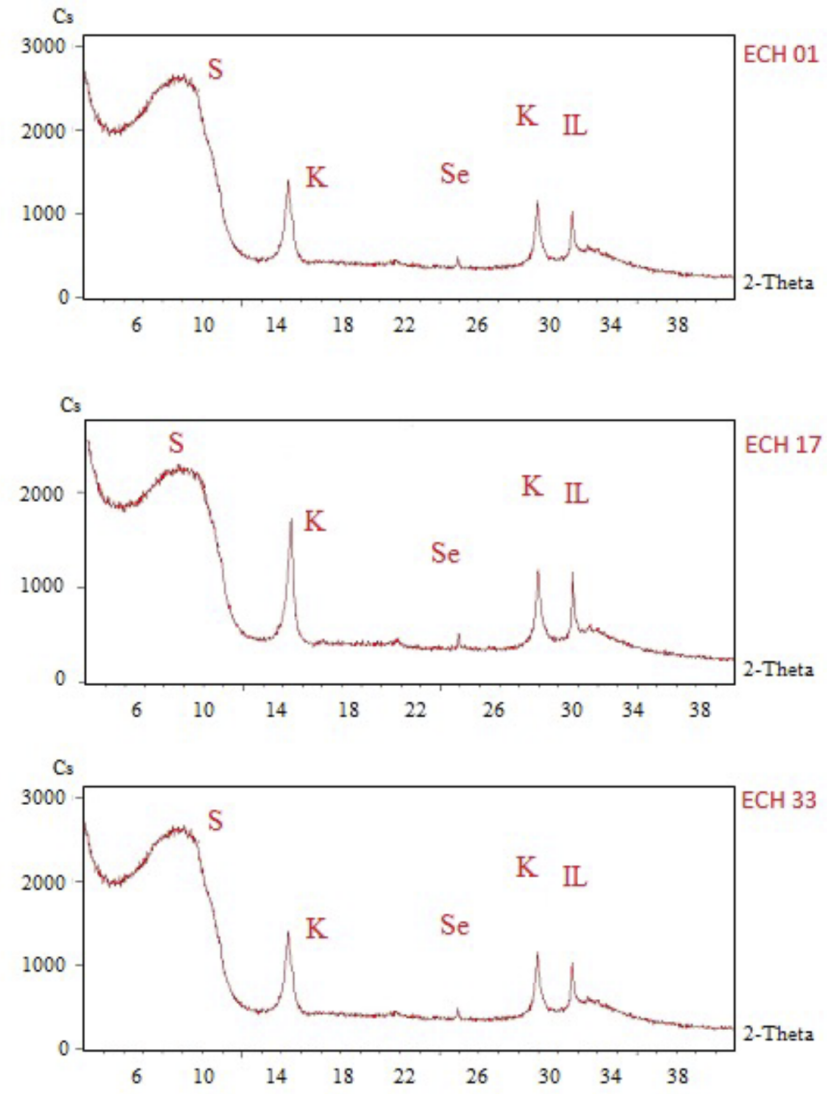

Figure 9. X-Ray diffractogram for clay mineralogy of some representative samples. On the $Y$ axis: CPS: counts per second. On the $X$ axis, $2 \theta$ in degree. (S: Smectite; K: Kaolinite; Se: Sepiolite; IL: Illite). 


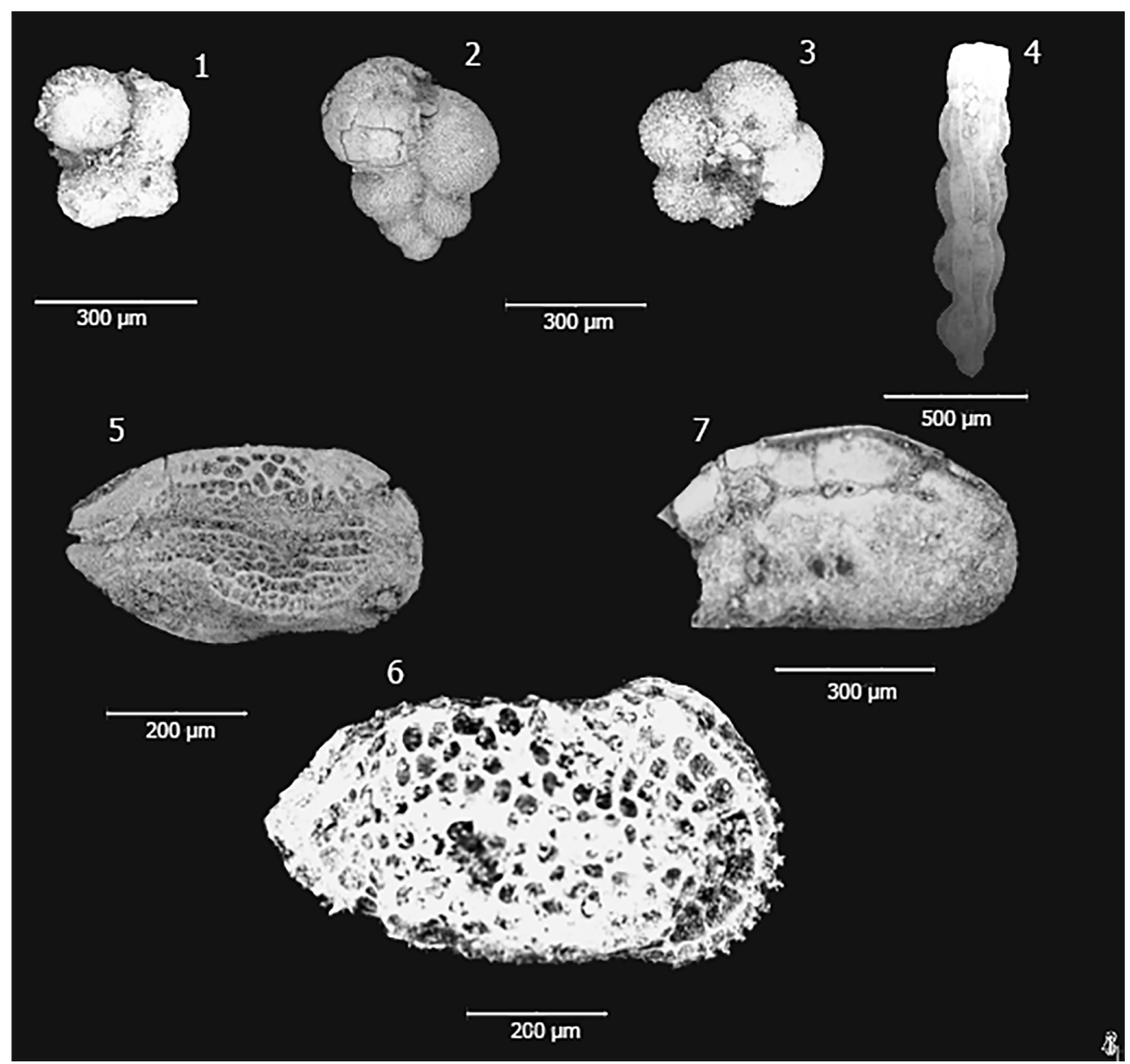

Figure 10. Foraminifer from the upper Miocene of El Ma Labiod showing: (1) Neogloboquadrina acostaensis; (2) Neogloboquadrina sp.; (3) Buliminasp; (4) Marginulina sp.; Ostracods; (5) Semicytherura? sp.; (6) Tenedocythere? sp.; (7) Paracypris? sp.

The drop in bathymetry is inferred by the common presence of benthic foraminifera Brizalina sp group and ostracoda. Among the most abundant genera; Tebedocythere? spp., Semicytherura? spp., Paracypris? spp and Grinioeis? spp., (Figure 10) which represent all together around $90 \%$ of the total number of specimens. Most of these taxa have been recognized as infralittoral taxa [Abad et al., 2005: Rundić, 2006; Shahin, 2000.

From a paleo-geographic view, the Miocene deposits of Tébessa region correspond to the second epirogenic episode, which consists of a more complex subsidence. The latter, is followed by an uplifting accompanied by alternative continental sediments [Hamimed and Kowalski, 2001]. The Tortonian deposit is subdivided into two main facies. The lower Tortonian consists of sands that unconformably overlay the Cretaceous series with a dis- tinguish hard-ground. The latter is widely used for the stratigraphic correlation in the Tébessa region. The upper Tortonian consists of clay [Vila et al., 1977]. The Tortonian is complex sedimentary system that refers to transitional facies into a mixt environment between fluvial, deltaic and lagoonal environment [Kowalski et al., 1995a]. The Miocene sediments were intensity eroded, and then they were deposit in shallow basins.

Along these sedimentological parameters associated with these new micropalentological data, the Miocene sediments are deposited in marginallittoral from El Hadjra Safra during the Tortonian interval similar to the Tortonian of Argoub Zitoun in l' Aouinet basin (sandy neritic sediment) [Kowalski et al., 1995a which may be related to tortonian sediment in Tazault and North-Western Tunisia according Villa's interpretations [Vila et al., 1977]. 


\section{Conclusion}

During the course of this study, a new sedimentological and micropaleontological data had been recorded on the Miocene of the Hadjra Safra region (Tébessa, northeastern Algeria). The grain size results reveal that sediments are composed of fine particles size (less than $50 \mu \mathrm{m}$ ); usually unimodal to bimodal curves of sands and silts. The morphoscopic observations indicate aquatic transport proximity of littoral appearance. The record of index species Neogloboquadrina acostaensishave been reported for first time from El Hadjera section, indicating Tortonian interval compared to Mediterranean scale Sea. The foraminifera and ostracods association indicate shallowest environment presence during Tortonian.

Acknowledgments. We thank Pr. Tuna Eren (İzmir Katip Çelebi University, Petroleum and Natural Gas Engineering, İzmir/Turkey) for the English editing.

\section{References}

Abad, M., R. Francisco, et al. (2005), Tortonian ostracodes of Southwestern Europe, Geobios, 38, 563-573, Crossref

Anderson, J. R. (2007), Sand Sieve Analysis, Pamela J. W. Gore "Historical Geology Online Laboratory Manual" p. 278, Department of Geology, Georgia Perimeter College, Georgia.

Benhenni, L., Y. Quesnel, et al. (2019), Joint modeling of potential-field data and geodynamic interpretation for northeast Algeria, Journal of African Earth Sciences, 159, 103,566, Crossref

Benzina, M., H. Hebib, M. Bensalah (2019), New insights in late Miocene lower Chelif basin biostratigraphy based on planktonic foraminifera (Algeria), Revue de Micropaléontologie, 62, 9-24, Crossref

Blés, J. L., J. J. Fleury (1970), Carte Géologique au 1/50,000 de Morsott (no 178), Pub. Serv Carte géologié, Algérie, Alger.

Blow, W. H. (1969), Late Middle Eocene to Recent Planktonic Foraminiferal Biostratigraphy, Bronnimann, P. and Renz, H. H. (Eds.), Proceedings of the 1st International Conference on Planktonic Microfossils, Vol. 1 p. 199-422, E. J. Brill, Geneva.

Brives, A. (1919), On the discovery of a Dinotherium tooth in the sandpit of El Kouif near Tebessa, Bull. Soc. Hist. Nat. Afr. Nord, X, No. 5, 90-93.

Brives, A. (1920), On the Presence of Mastodon in the Sandpit of El Kouif, C.R.S.G.F., No. 17, 212.

Cailleux, Tricart (1963), Initiation à l'étude des sables et des galets, 369 pp. Centre de Documentation Universitaire, Paris.
Chabou-Mostefai, S. (1987), Etude de la série phosphatée tertiaire du Djebel Onk, Algérie, Stratigraphie, Pétrographie, Minéralogie et Analyse Statistique, Doctor Theses, p. 376, Université d'Aix-Marseille, France.

Chameley, H. (1971), Sur les mineraux argileux des terrasses pleistocenes du confluent, Rhone-Isere Quaternaire, 11, No. 2, 61-64.

Cherif, A., M. N. Naimi, M. Belaid (2021), Deepsea trace fossils and depositional model fromthe Lower Miocene Tiaret Marls Formation (northwestern Algeria), Journal of African Earth Sciences, 175, 104115, Crossref

Defaflia, N. (2014), Cadre Stratigraphique et paleoenvironnemental des formations quaternaires de la region d'El Ma El Abiod (Tébessa, Algerie), Doctor Theses, University of Tebessa, Algerie.

Dubourdieu, G. (1956), Geological Study of the Ouenza Region (Algerian-Tunisian Borders), 659 pp. Publ. Serv. Geolog. Map of Algeria, Algeria.

Dubourdieu, G., L. Hottinger (1959), The presence of Neoalveolinae within the Mesloula Miocene (eastern Algeria), Micropal. Rev., 2, No. 1, 3-7.

Durand-Delga, M. (1969), Mise au point sur la structure du Nord-Est de la Berberie, Publications du Service de la Carte Geologique de l'Algerie, 39, 89131.

Durozoy, G. (1956), Geological Map of Algeria at 1/50,000 of Tebessa (no 206), Geolog. Map Serv. of Algeria, Algier.

Durozoy, G., M. Bouillon (1956), Carte Géologique de l'Algérie au 1/50,000. Feuille 206. Tébessa, Service de la Carte Géologique de l'Algérie, Algier.

Folk, P., W. Ward (1957), Brazos river bar: a study in the significance of grain size parameters, Journal of Sedimentary Petrology, 27, 3-26, Crossref

Fournier, J., C. Bonnot-Courtois, et al. (2012), Granulometric Analyzes, Principles and Methods, 99 pp. CNRS, Dinard.

Gammudi, A., M. C. Kee (1993), Ostracoda from the Miocene Marada Formation of Libya, J. Micropalaeontol., 12, 121-139, Crossref

Goodman, D. K. (1979), Dinotlagellates "communities" from the lower Eocene Nanjemoy formation of Maryland, U.S.A., Palynology, 3, 169-190.

Halamski, A. T., A. Cherif (2017), Oxfordian brachiopods from the Saïda and Frenda mountains (Tlemcenian domain, North-western Algeria), Annales Societatis Geologorum Poloniae, 87, 141156, Crossref

Hamimed, M. (2004), Étude sédimontologique et paléogéographie des sédiments miocènes au pays du Nord-Est de l'atlas saharien des confins Algéro-Tunisiens, Ph. D. Thesis, University of Constantine, Algeria.

Hamimed, M., W. M. Kowalski (2001), Sedimentological analysis and paleogeography of the Miocene sediments (Langhian-Serravalian) of the surroundings of Tebessa (North-East of Algeria), Bull. Geol. Serv. of Algeria, 12, 49-75. 
Hebib, H., $\quad$ L. Belkebir (2006), Évolution des assemblages des foraminiféres benthiques du Miocéne supérieur (exemple de la marge sud du Bas Chélif). [Evolution of the assemblies of the Benthic foraminifera of Upper Miocene (example of South margin of the lower Chelif basin], Mémoire du Service Géologique National, 13, 263-273.

Holtzapffel, T. (1985), Les mineraux argileux; preparation, analyse diffractometrique et determination, Société Géologique du Nord, 12, 136.

Inman, D. I. (1952), Measures for describing the size distribution of sediments, Journal Sediment Res., 22, 125-145, Crossref

Jenkyns, H. C. (2010), Geochemistry of oceanic anoxic events, Geochemistry Geophysics Geosystems, 11, No. 3, 1-30, Crossref

Kazi-Tani, N. (1986), Evolution geodynamique de la bordure nord-africaine: le domaine intraplaque nordalgerien. Approche megasequentielle, Doctor Theses, p. 871, Universite de Pau et du Pays de l'Adour, France.

Kechiched, R., R. Laouar, et al. (2016), Preliminary data of REE in Algerian phosphorites: a comparative study and paleo-redox insights, Procedia Engineering, 138, 19-29, Crossref

Kechiched, R., R. Laouar, et al. (2018), Glauconitebearing sedimentary phosphorites from the Tébessa region (eastern Algeria): Evidence of REE enrichment and geochemical constraints of their origin, Jour nal of African Earth Sciences145,190-200, Crossref

Kechiched, R., R. Laoua, et al. (2020), Comprehensive $\mathrm{REE}+\mathrm{Y}$ and sensitive redox trace elements of Algerian phosphorites (Tébessa, eastern Algeria): A geochemical study and depositional environments tracking, Journal of Geochemical Exploration, 208, 106,396, Crossref

Kowalski, W. M., N. Van Ngoc, et al. (1995a), Miocene paleogeography of El Aouinet area (Northern Tebessa), NE of Algeria, Univ. Sci. Ann. of Fr-Comte, Besanson, 4, No. 12, 55-61.

Kowalski, W. M., A. Pharisat, M. Hamimed (1995b), Sedimentological analysis of Miocene sands around Tebessa (Algerian-Tunisian borders), Univ. Sci. Ann. of Fr-Comte, Besanson, 4, No. 12, 45-54.

Kouwenhoven, T. J. (2000), Survival under stress: Benthic foraminiferal patterns and Cenozoic biotic crises, Geol. Ultraiect., 186, 1-206.

Laouini, H., M. Hacini, et al. (2019), Sedimentological and paleoenvironmental analysis of chott Baghdad deposit (Northern Algerien Sahara), Energy Procedia, 157, 59-67, Crossref

Levin, L., J. D. Cage (1998), Relationships between oxygen, organic matter and the diversity of bathyal macrofauna, Deep-Sea Research II, 45, 129-163, Crossref

Lirer, F., L. M. Foresi, et al. (2019), Mediterranean Neogene planktonic foraminifer biozonation and biochronology, Earth Science Reviews, 196, 136, Crossref
Lourens, L., F. Hilgen, et al. (2005), The Neogene Period, A Geologic Time Scale 2004, Gradstein, F. M., Ogg, J. G., Smith, A. G. (Eds.) p. 409-440, Cambridge University Press, Cambridge. Crossref

Mendir, S., S. Salmi-Laouar, et al. (2019), Les ammonites du Cenomanien des massifs de Hameimat (Tébessa, Atlas saharien oriental, Algerie): systematique et biostratigraphie, Revue de Paleobiologie, 38, No. 1, 229-254, Crossref

Millot, G. (1964), Geologie des Argiles, 499 pp. Masson, Paris.

Miskovsky, J. C. (2002), Geologie de la Prehistoire, methodes, techniques, applications. Association pour l'etude de l'environnement geologique de la Prehistoire, 1519 pp. Presses Universitaires de Perpignan, Paris.

Morel, F. (1957), Étude Géologique du Djebel Belkfif' (Tebessa), Bull. no 13, Pub. Sérv. Carte Géol. Algérie, Algérie.

Murray, J. W. (1991a), Ecology and Palaeoecology of Benthic Foraminifera, 1-397 pp. Longman Harlow, Harlow.

Murray, J. W. (1991b), Ecology and distribution of benthic foraminifera, Biology of Foraminifera, Lee, J. J., Anderson, O. R. (Eds.) p. 221-254, Academic Press, New York.

Naimi, M. N., B. Mansour, et al. (2020), Lithostratigraphie et paleoenvironnements des depots messiniens du Djebel Aoud Sma (bassin du Bas Chelif, Algerie nord-occidentale), Revue de Paleobiologie, 39, 467-483.

Naimi, M. N., O. Vinn, A. Cherif (2021), Bioerosion in Ostrea lamellosa shells from the Messinian of the Tafna basin (NW Algeria), Carnets de Géologie, 21, 127-135, Crossref

Othmanine, A. (1987), Les minéralisations en fluorine, barytine, $\mathrm{Pb}, \mathrm{Zn}$ et fer sideritique autour du fosse de Tebessa-Morsott (Algerie). Relation entre paleogeographie aptienne, diapirisme, structure et metallogenie, 221 pp. Universite Pierre et Marie Curie, Paris VI, France.

Paquet, H. (1969), Evolution geochimique des mineraux argileux dans l'alteration et les sols des climats méditerranéens et tropicaux a saisons contrastees, Doctor Theses, p. 348, University of Strasbourg, Strasbourg.

Pinot, J. P. (1994), Manipulations Sedimentologiques Courantes M.W. TURGAL.07, 118 pp. Edition de fevrier, SEDI.

Pye, K., S. J. Blott (2004), Particle size analysis of sediments, soils and related particulate materials for forensic purposes using laser granulometry, Forensic Science International, 144, 19-27, Crossref

Rivière, A. (1977), Methodes Granulometriques, Technique et Interpretation, 170 pp. Edition Masson, Paris.

Ruault-Djerrab, M., F. Kechid-Benkherouf (2011), Micropaleontological study (foraminifera, ostracods) 
and characterization of the paleoenvironment of middle Cretaceous deposits (Djebel Chemla area, northeastern Algeria), Arabian Journal of Geosciences, 4, 1289-1299, Crossref

Ruault-Djerrab, M., B. Ferré, F. Kechid-Benkherouf (2012), Etude micropaleontologique du CenomanoTuronien dans la region de Tébessa (NE Algerie): implications paleoenvironnementales et recherche de l'empreinte de l'OAE2, Revue de Paleobiologie, 31, No. 1, 127-144.

Ruault-Djerrab, M., F. Kechid-Benkherouf, A. Djerrab (2014), Donnees paleoenvironnementales sur le Vraconnien/Cenomanien de la region de Tébessa (Atlas Saharien, nord-est Algerie). Caracterisation de l'OAE2, Annales de Paleontologie, 100, 343-359, Crossref

Rundić, L. J. (2006), Late Miocene ostracods of Serbia: morphologic and paleoenvironment considerations, GeoloŠki Anali Balkanskoga Poluostrva, 67, 89-100.

Salmi-Laouar, S., B. Ferré, et al. (2018), The oceanic anoxic event 2 at Es Souabaa (Tebessa, NE Algeria): bio-events and stable isotope study, Arabian Journal of Geosciences, 11, 182, Crossref

Shahin, A. (2000), Tertiary ostracods of Gebel Withr, southwestern Sinai, Egypt: palaeontology, biostratigraphy and palaeobiography, Journal of African Earth Sciences, 31, No. 2, 285-316, Crossref

Shannon, C. F., W. Weaver (1949), The Mathematical Theory of Communication, $322 \mathrm{pp}$. University of Illinois Press, Urbana (Illinois).
Soria, J. M., J. E. Caracuel, et al. (2005), The stratigraphic record of the Messinian salinity crisis in the northern margin of the Bajo Segura Basin (SE Spain), Sedimentary Geology, 179, 225-247, Crossref

Sprovieri, R., S. Bonomo, et al. (2002), Anintegratedcalcareous plankton biostratigraphic scheme and biochronology for the Mediterranean Middle Miocene, RivistaItaliana di Paleontologia e Stratigrafia, 108, 337-353.

Tricart, J. (1965), Principles and Methods of Geomorphology, 496 pp. Masson and Cie, Paris.

Verger, F. (1963), Les Techniques d'Analyse Granulometrique. Memoires et Documents, tome IX, fasc. 1, 64 pp. CNRS, Paris.

Vila, J. M. (1977), Carte geologique de l'Algerie au 1/200,000, feuille de Constantine (P-Q;3-4), avec notice explicative detaillee, $45 \mathrm{pp}$. Publ. Comm. Serv. Carte Geol. Algerie/SONATRACH, Algerie.

Vila, J. M. (1980), La chaíne alpine d'Algérie orientale et des confins algéro-tunisiens, 2 tomes, Thèse doctorat d'état, p. 665, Pris VI, Algerie.

\section{Corresponding author:}

Abdelhakim Benkhedda, Laboratory of Sedimentary Environment, Mineral and Hydric Resources of Algeria Eastern, Departement of Geology, University of Larbi Tebessi, Tébessa, Algeria. (abdelhakim.benkhedda@univ-tebessa.dz) 